\title{
RESEARCH IN DYNAMIC TRANSITIONAL PROCESSES OF FUNCTIONING OF COMBINE HARVESTER HYDRAULIC DRIVES
}

\author{
Volodymyr Bulgakov $^{1}$, Semjons Ivanovs ${ }^{2}$, Vadym Yaremenko ${ }^{1}$, Francesco Santoro ${ }^{3}$ \\ ${ }^{1}$ National University of Life and Environmental Sciences of Ukraine, Ukraine; \\ ${ }^{2}$ Latvia University of Life Sciences and Technologies, Latvia; \\ ${ }^{3}$ University of Bari Aldo Moro, Italy \\ semjons@apollo.lv
}

\begin{abstract}
An analysis of perspective methods is made for diagnosing hydraulic drives, based on the on-board automated tools. Prospects are substantiated for the development of technical diagnostics of agricultural machinery on the basis of on-board electronic means. Special attention is paid to the need for significant research in the direction of creating new diagnostic parameters, adapted to these means, and methods of their measurement. The parameters of the characteristics of changes in the pressure of the working fluid in the hydraulic aggregates in transitional modes of operation of the hydraulic drives are advisable to be used as diagnostic, since the veracity (accuracy) of the parameters, based on them, is not less than 95\%. As an example, a method of diagnosing on dynamic transitional modes of operation of the hydraulic drives is given, which is the basis for the development and use of built-in and portable electronic means for conducting CIP diagnostics, which will provide 2-3 times decrease in the labour intensity and the cost of work with at least $85 \%$ veracity of diagnosis and the permissible error measurements no more than $\pm 4 \%$. The novelty of this work lies in the method we have developed for diagnosing the dynamic transient modes of operation of hydraulic drives.
\end{abstract}

Keywords: diagnostics, transitional processes, combine harvesters, hydraulic drive.

\section{Introduction}

Maintaining proper technical readiness of agricultural machinery in the process of agricultural operations is a reason to increase the quality of the product and to decrease the costs [1]. Contemporary tractors and combine harvesters have a fairly high level of hydrofication of the mechanisms that require an appropriate level of maintenance. Grain harvesters are complex agricultural machinery with a hydraulic drive of the most important units, the power of their engines is constantly increasing [2]. One of the aspects of increasing the technical readiness of the equipment is timely warning and troubleshooting [3-9].

Research and diagnostics of the condition of the hydraulic equipment of agricultural tractors, combine harvesters and machines is an urgent practical and scientific problem. Despite the fairly widespread use of the on-board electronic means [10-12], not enough attention is paid to the technical diagnostics of the hydraulic drives, although almost $25 \%$ of faults, out of the total number of tractors and combine harvesters, are accounted for by the hydraulic drives. In modern combines, depending on their purpose, the steering, the running system and most of the technological mechanisms are hydraulic. The level of hydrofication can be roughly estimated by the cost of the components, which on some harvesters is about $30 \%$ of the total cost of the harvester.

Therefore, the occurrence of a failure in a separate hydraulic unit or its component part leads to a partial or complete loss of performance of the hydraulic mechanism and the combine. Prospects for the development of technical diagnostics of the equipment, based on the on-board electronic means, are described in the works [10]; special attention is paid to the need for significant research in the direction of creating new, adapted to these means, diagnostic parameters and methods of their measurement. A thorough analysis of the perspective methods for diagnosing the hydraulic drives of the aviation and rocket technology, based on the on-board automated means, is given in the work [13], in which special attention is focused on the possibility to use these means for other kinds of technology. A possibility to diagnose the tractor gearbox in non-transient modes is considered in [14], using the time of the transitional process (according to the parameters of the pressure variations of the working fluid in the cavities of the hydraulic units) from the beginning of turning off one fluid coupling until the end of turning on the other, and the time of the gear overlap as diagnostic parameters.

The purpose of this work is to substantiate the diagnostic parameters for determining the technical condition of a hydraulic drive of combines in transitional modes of their functioning, which provide the smallest values of the complexity of diagnostics and are the basis for creating electronic diagnostic tools. 


\section{Materials and methods}

The conducted theoretical studies formulated hypotheses of possible methods for diagnosing hydraulic drives and developed diagnostic models of structural and functional relationships of the interaction of internal and external input and output parameters of hydraulic units. To confirm theoretical studies and the validity of the obtained dependences, experimental studies were carried out.

The following experimental studies were carried out: determination of the nature of changes in the structural parameters of parts and their influence on the parameters of the technical state of hydraulic units; a physical model of equipment for laboratory research of static and dynamic modes of functioning of hydraulic drives of combines has been developed and manufactured; a method for measuring the parameters of the functioning of hydraulic drives in static and dynamic modes has been developed; the regularities of changes in the parameters of the technical state of hydraulic units and their influence on the performance indicators of the hydraulic mechanisms of combines are established; a methodology for assessing the results of technical diagnostics of hydraulic drives has been developed; determination of diagnostic parameters of objects to be diagnosed and construction of algorithms for finding failures and determining the technical state of hydraulic drives as a whole and their components. After determining the parameters and constructing graphs of the empirical distribution of wear on the surfaces of parts, the empirical distribution was aligned according to the laws of theoretical distribution. Most of the hydraulic drives can be represented by a diagram (Fig. 1).

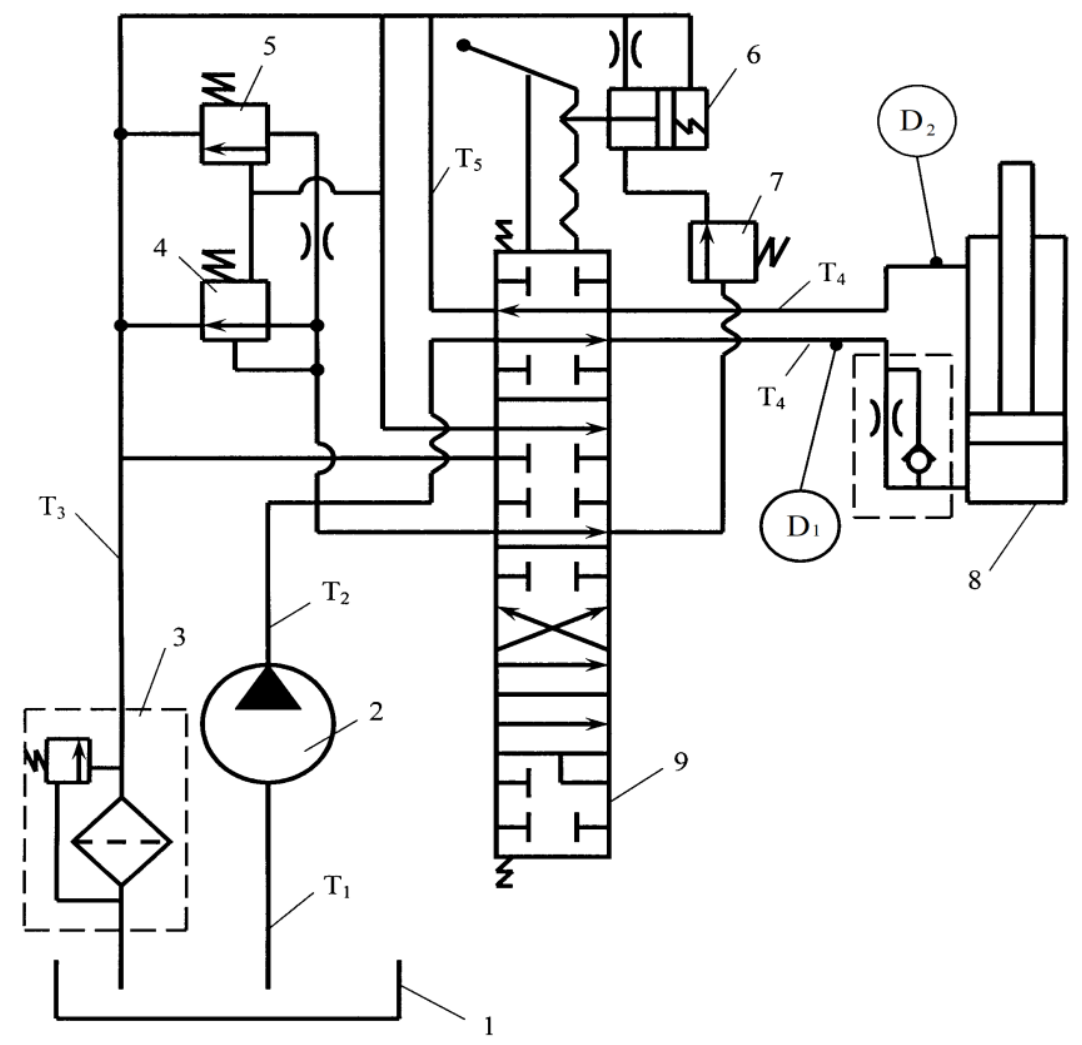

Fig. 1. Schematic diagram of the hydraulic drive and the place of connection of the sensors for

fixing the diagnostic signals in transitional modes of operation: 1 - tank; 2 - pump; 3 - filter; 4 - distributor bypass valve; 5 - distributor safety valve; 6 - device for fixing the spool in working positions; 7 - booster valve; 8 - hydraulic cylinder; 9 -distributor spool; D1 - pressure sensor at the inlet to the hydraulic cylinder; D2 - pressure sensor at the outlet of the hydraulic cylinder

It is typical for the hydraulic drives of the combine harvesters that they operate in unstable dynamic transitional modes, accompanied by a change in the speed and direction of the movement of the moving parts of the mechanisms and the flow of the working fluid, as a result of which the pressure of the working fluid changes. In the case of a quick stop of the movable parts of the hydraulic mechanisms and the flow of the working fluid, the kinetic energy of moving the movable parts and the working fluid is 
transformed into the potential energy of the spring deformation of the working fluid and hydraulic drive parts, which leads to a sharp increase in the pressure of the working fluid (hydraulic shock):

$$
\left.\begin{array}{l}
-\frac{d P}{d x}=\rho\left(\frac{d v}{d t}+2 a v\right), \\
-\frac{d P}{d t}=c^{2} \cdot \rho \frac{d \omega}{d x}=K \frac{d \omega}{d x},
\end{array}\right\},
$$

where $P$-average pressure of the working fluid in the pipeline (hydraulic cylinder), MPa;

$v$-average value of the speed of the working fluid, $\mathrm{m} \cdot \mathrm{s}^{-1}$;

$t$ - time, $\mathrm{s}$;

$a$-coefficient that depends on the cross-section and the wall thickness of the pipeline;

$K$ - reduced modulus of volumetric compression of the pipeline, $\mathrm{kg} \cdot \mathrm{cm}^{-2}$;

$x$ - direction of the flow of the fluid.

$$
c=\sqrt{\frac{K}{\rho_{0}}},
$$

where $c$-speed of the sound in a liquid that flows in the pipeline, $\mathrm{m} \mathrm{s}^{-1}$;

$$
\rho=\rho_{0}\left(1+\frac{P-P_{0}}{K_{P C}}\right),
$$

where $\rho$ - density of the working fluid, $\mathrm{kg} \cdot \mathrm{m}^{-3}$;

$\rho_{0}$ - density of the working fluid at pressure, $\mathrm{kg} \cdot \mathrm{m}^{-3}$;

$P_{0}$ - initial pressure, $\mathrm{MPa}$;

$K_{P C}-$ modulus of volumetric compression of the working fluid, $\mathrm{kg} \cdot \mathrm{cm}^{-2}$.

$$
K=\frac{K_{P}}{1+a \frac{K_{P}}{E}},
$$

where $K$ - reduced modulus of elasticity of the pipeline walls and the body of the hydraulic cylinder, $\mathrm{kg} \cdot \mathrm{cm}^{-2}$;

$E$ - elasticity modulus of the first kind of the pipe material (for steel $E=2 \cdot 10^{6} \mathrm{~kg} \cdot \mathrm{cm}^{-2}$ );

$K_{p}-$ working fluid pressure module, $\mathrm{kg} \cdot \mathrm{cm}^{-2}$.

For thin-walled pipes:

$$
a=\frac{d}{\delta_{0}},
$$

where $d$-diameter of the inner pipe, $\mathrm{m}$;

$\delta_{0}-$ thickness of the wall of the pipe, $m$.

\section{Results and discussion}

The conducted theoretical studies formulated hypotheses of possible methods for diagnosing hydraulic drives and developed diagnostic models of structural and functional relationships of the interaction of internal and external input and output parameters of hydraulic units. To confirm theoretical studies and the validity of the obtained dependences, experimental studies were carried out.

As a result of solving the system of equations (1) the increase in the pressure of the working fluid in the hydraulic drive in the dynamic transitional modes is determined by the following relationship:

$$
\Delta P=2 \cdot a \cdot \rho \cdot l \cdot \omega_{0}+\frac{4}{\pi} \cdot c \cdot \omega_{0} \cdot e^{-a t} \cdot \sum_{S=1}^{\infty} \frac{\sin \left(\xi_{S}-2 \theta_{S}\right)}{(2 S-1) \cos \theta_{S}},
$$

where $\Delta P$-increase in the pressure of the working fluid, MPa;

$l$ - length of the pipelines and the hydraulic cylinders in the working fluid supply line, $\mathrm{m}$; 
$\omega_{0}$ - speed of the overflow of the working fluid in the cavity of the hydraulic cylinder by the time the piston stops, $\mathrm{m} \cdot \mathrm{s}^{-1}$;

$\theta_{S}, \xi_{S}$ - coefficients depending on the working fluid and pipelines.

$$
\xi_{S}=\sqrt{\left(\frac{2 S-1}{2} \pi\right)^{2} \frac{c^{2}}{l^{2}}-a^{2}} .
$$

For short pipelines and not very viscous working fluids we can assume:

$$
\begin{aligned}
& \xi_{S} \approx \frac{2 S-1}{2} \cdot \frac{\pi \cdot c}{l} . \\
& \theta_{S} \approx 0 .
\end{aligned}
$$

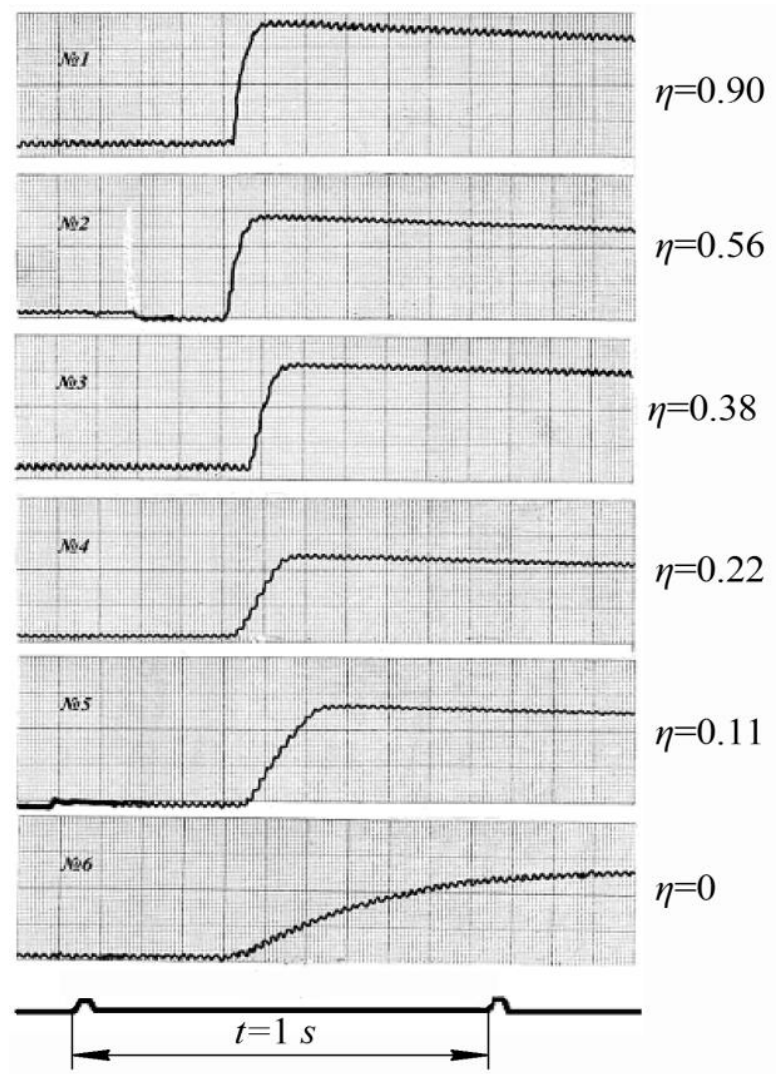

Fig. 2. Oscillograms of characteristics of changes in the pressure of the working fluid in the rodless cavity of the hydraulic cylinder steering of the combine harvester in case there is a change in the total volumetric efficiency

After analyzing the dependence (6), we proposed to use the characteristics of changes in the pressure of the working fluid in the transitional modes of operation of the hydraulic drives as diagnostic characteristics according to the obtained oscillograms, shown in Fig. 2, and depicting the differential pressure $(\Delta P)$. The assessment of the technical condition of the hydraulic drive as a whole, and its performance can be given, based on the measurements and analysis of the parameters of the characteristics of changes in the pressure of the working fluid in the hydraulic drives in transitional modes of their operation. It is obvious that the nature of the change in the pressure of the working fluid in the cavity of the hydraulic cylinder occurs, as shown in Fig. 3. It has been experimentally established that the change in the volumetric efficiency of the hydraulic drive from 0.90 to 0 leads to the following changes in the pressure parameters of the working fluid in case the piston of the hydraulic cylinder stops: the maximum pressure of the working fluid $\left(P_{2}\right)$ decreases from 16.50 $\mathrm{MPa}$ to $8.90 \mathrm{MPa}$; the pressure $\left(\Delta P_{1}\right)$ decreases from 15.95 MPa to 8.39 MPa; the time of the pressure increase $\left(\Delta t_{1}\right)$ increases from $0.065 \mathrm{~s}$ to $0.190 \mathrm{~s}$; the time of the pressure decrease $\left(\Delta t_{2}\right)$ changes from $4 \mathrm{~s}$ to $160 \mathrm{~s}$, (Fig. 4, Fig. 5). 


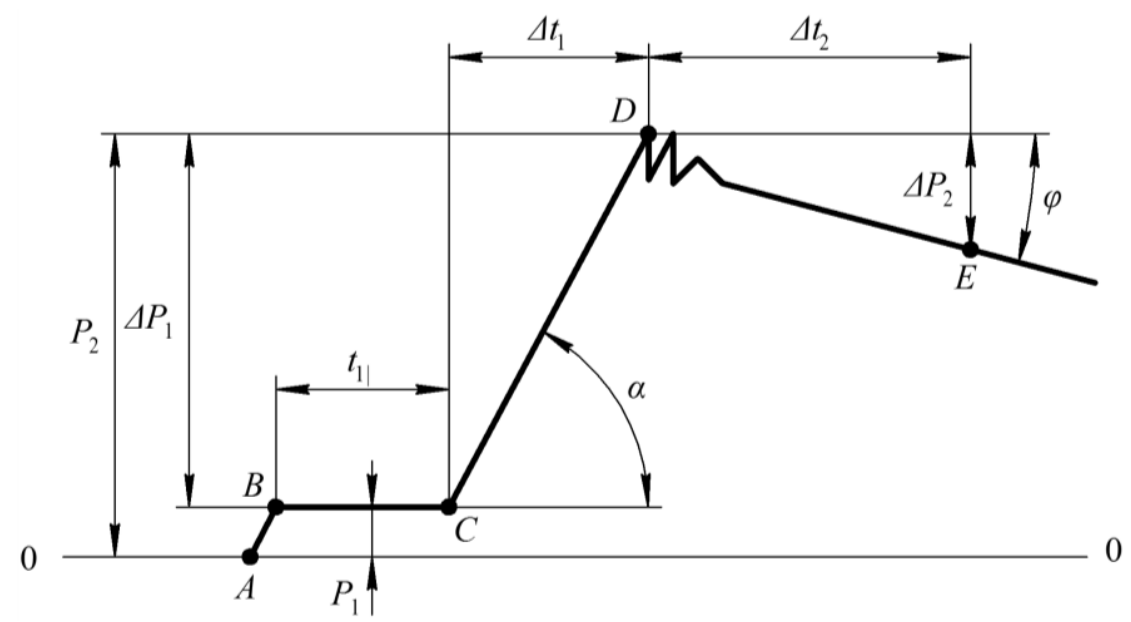

Fig. 3. Diagram of the nature of the change in pressure of the transitional process of functioning of the hydraulic drive: pressure of the working fluid in the cavities of the hydraulic cylinder in a neutral position of the valve spool; $A$ - moment when the spool is turned on into the working position; $B$ - moment when the piston of the hydraulic cylinder starts moving; $C$-moment when stopping the piston of the hydraulic cylinder stops moving; $D$ - moment when the maximum pressure of the working fluid is reached and the spool valve returns to a neutral position; $E$-moment when the pressure of the working fluid decreases to the permissible value; $P_{1}$ - pressure of the working fluid in the idle stroke of the piston of the hydraulic cylinder; $P_{2}$ - maximum pressure of the working fluid in the cavity of the hydraulic cylinder after the piston stops; $\Delta P_{1}$-increase in the pressure of the working

fluid due to hydraulic shock; $\Delta P_{2}$-reducing pressure of the working fluid due to the loss of the working fluid in the interfaces of the parts of the hydraulic units; $t$ - time of the movement of the piston of the hydraulic cylinder; $\Delta t_{1}$ - time of increasing the pressure of the working fluid; $\Delta t_{2}-$ time of decreasing the pressure of the working fluid; $\alpha$ - angle of inclination to the abscissa axis of the characteristic of increasing the pressure of the working fluid; $\varphi$ - angle of inclination to the abscissa axis of the characteristic of reducing the pressure of the working fluid

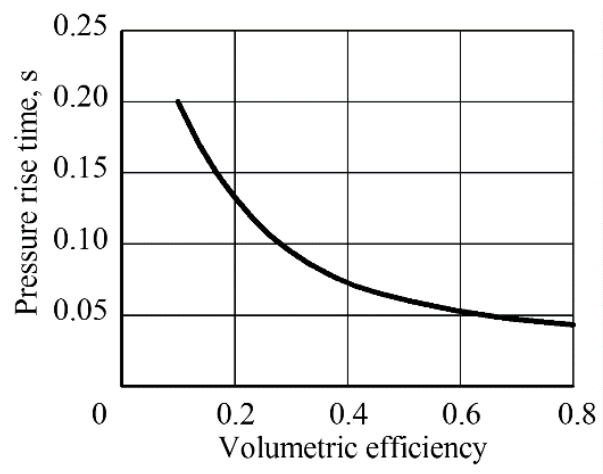

Fig. 4. Dependence of the time $\left(\Delta t_{1}\right)$ of the pressure increase of the working fluid in the cavity of the hydraulic cylinder in the case when the movement of the piston stops upon the volumetric efficiency

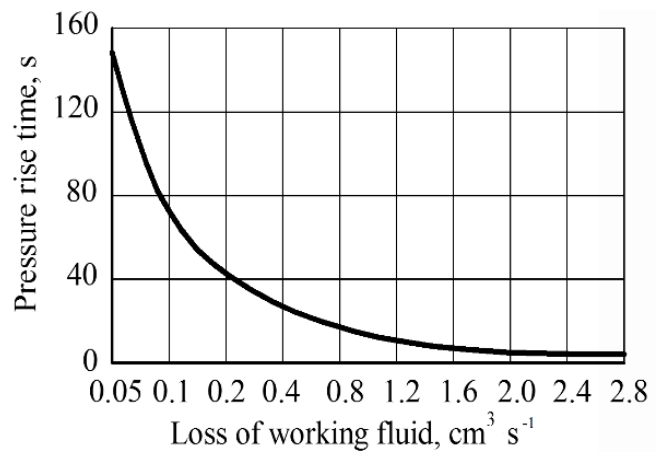

Fig. 5. Dependence of the pressure decrease time of the working fluid in the cavity of the hydraulic cylinder $\left(\Delta t_{2}\right)$ from 10 MPa to 5 MPa upon the losses of the working liquid $\left(\Delta Q_{2}\right)$ in the interfaces between the distributor valve body and the piston with the body and rod of the hydraulic cylinder body; the valve spool is set to the position "Neutral"

Checking the results of the oscillography of the dynamic process in the transitional modes indicates that the reliability of the technical parameters of the characteristics of the change in the pressure of the working fluid is at least $95 \%$. In addition, the labour intensity of express diagnostics, in the case the built-in or portable electronic diagnostic tools are used, for these diagnostic parameters is more than 0.06 man-hours, which is 3-4 times less than diagnostics by the mechanical means. An analysis of the relevant technical literature of countries with developed mechanical engineering $[3 ; 4 ; 7-9]$ shows that 
the proposed method for diagnosing hydraulic drives based on the characteristics of changes in the pressure of the working fluid in hydraulic units (in the event of a stop or change in the direction of movement of moving parts and the flow rate of the working fluid) is especially relevant to improve the technical readiness of agricultural machinery and reduce the maintenance and repair costs. This method can be the basis for the development and application of built-in and portable electronic tools for conducting CIP diagnostics, which provide a reduction in the maintenance and repair costs.

\section{Conclusions}

1. The parameters of the characteristics of changes in the pressure of the working fluid in the hydraulic aggregates in transitional modes of operation of the hydraulic drives are advisable to be used as diagnostic, since the veracity (accuracy) of the parameters, based on them, is not less than $95 \%$.

2. The method of diagnostics in the dynamic transitional modes of the hydraulic drives of operation is the basis for the development and application of the built-in and portable electronic means for conducting CIP diagnostics, which will ensure a 2-3 times decrease in the labour intensity and cost with the veracity of the diagnosis not less than $85 \%$ and the permissible measurement error not more than $\pm 4 \%$.

\section{References}

[1] Димитров В.П., Ильченко В.Д., Смирнов Б.Н. 2000. Построение экспертной системы для диагностики зерноуборочных комбайнов. Тракторы и сельскохозяйственные машины. (Construction of an expert system for diagnostics of combine harvesters. Tractors and agricultural machines), No 3, pp. 6-8. (In Russian)

[2] Viesturs D., Kopiks N. Investigations in suitability of fleet of combines for timely harvesting. Engineering for Rural Development, 2016, pp. 681-686.

[3] Piramatov U.A., Pugin K.G. Improving the efficiency of existing methods of diagnosing the hydraulic drive of road-building machines. IOP Conference Series: Materials Science and Engineering, 786(1), 2020, art. 012007

[4] Wang F., Zhang H., Xu B., Stelson K.A. Steady-State Characteristics Study of a Power Split Hydraulic Transmission. IEEE/ASME Transactions on Mechatronics, 26(1), 2021, art. 9113430, pp. 78-89

[5] Шипиловский Т., Архипов В. Перспективы развития диагностики технического состояния тракторов на основе бортовых электронных средств. Тракторы и сельскохозяйственные машины (Prospects for the development of diagnostics of the technical condition of tractors based on on-board electronic means. Tractors and agricultural machines,), 2004, No 7, pp. 3-7 (In Russian)

[6] Haifei W., Zhonghua Z., Chuanling Z. Modeling and simulation of sugarcane harvester hydraulic system based on amesim. Journal of Chong Qing JiaoTong Univesity (Natural Science), 2013, 32 (5), pp. 1063-1067

[7] Bao Y. Working principle and precautions for the use of grain combine harvester. Agricultural Machinery Use and Maintenance. 2018, p 54.

[8] Gao Y., Kong X., Zhang Q. Wavelet packets analysis based method for hydraulic pump condition monitoring. Jixie Gongcheng Xuebao/Journal of Mechanical Engineering 45(8), 2009, pp. 80-88

[9] Wang, H., Shen, H., Cao, S. Hydraulic System Design of Combined Harvester Header and Simulation of Header Lifting System. IOP Conference Series: Earth and Environmental Science. Volume 233, Issue 3, 2019, Article number 0320122018

[10] Иванишин В., Коваль С., Ковпак А. Бортовое электронное устройство для тракторов. Техника АПК (On-board electronic device for tractors. Agroindustrial complex technology). 2006, No, pp. 6-8. (In Ukrainian)

[11] John Deere Harvester Works. TM 2702. Combine 9400, 9500, 9600 testing and diagnostics. 1997. $2219 \mathrm{p}$.

[12] Ivanovs S., Bulgakov V., Nadykto V., Ihnatiev Y., Smolinskyi S., Kiernicki Z. Experimental study of the movement controllability of a machine-and-tractor aggregate of the modular type. INMATEH - Agricultural Engineering. Vol.61 (2), 2020, pp.9.-16 
[13] Воскобойник М. Загребельный В., Милов М. Об использовании параметров температурного поля для диагностирования насосов самолетных гидросистем. Совершенствование методов технической эксплуатации летательных аппартатов. (On the use of the parameters of the temperature field for diagnosing the pumps of aircraft hydraulic systems. Improvement of methods of technical operation of aircraft), 1983, Rīga, pp. 47-50 (In Russian)

[14] Яременко В.М., Яременко В. В. Б Одинцов Ю. Диагностирование гидроприводов на переходных режимах их функционирования. Механизация и электрификация сильского господарства. (Diagnostics of hydraulic drives in transient modes of their functioning. Mechanization and electrification of agriculture), 2009, Vol. 93, Glevakha, pp. 408-417. (In Ukrainian) 